\title{
Pretreatment of Starch-Free Sugar Palm Trunk (Arenga pinnata) to Enhance Saccharification in Bioethanol Production
}

\author{
Kusmiyati $^{1, *}$, Duwi Maryanto ${ }^{1}$, Ringga Sonifa $^{1}$, Sabda Aji Kurniawan ${ }^{1}$, and H. Hadiyanto ${ }^{2,3}$ \\ ${ }^{1}$ Renewable Energy Research Centre, Department of Chemical Engineering, Faculty of Engineering, \\ Universitas Muhammadiyah Surakarta, J1. A. Yani Tromol Pos 1, Pabelan, Kartasura 57102, Surakarta, Indonesia \\ ${ }^{2}$ Department of Chemical Engineering, Faculty of Engineering, Diponegoro University, Jl. Prof. Soedarto, SH-Tembalang Semarang \\ 50275, Indonesia \\ ${ }^{3}$ Master Program of Environmental Science, School of Postgraduate Studies, Diponegoro University, Jl. Imam Bardjo, SH-Semarang \\ 50241
}

\begin{abstract}
Starch-Free Sugar Palm Trunk (Arenga pinnata) can be utilized to produce bioethanol because of their high lignocellulosic contents. Production of bioethanol from lignocellulosic materials consist of pre-treatment, saccharification and fermentation processes. In this work, conversion of starch-free sugar palm trunk (Arenga pinnata) to fermentable sugar and bioethanol was carried out through g pretreatment, saccharification and fermentation processes. The pretreatment was carried out by addition of $1 \%(\mathrm{v} / \mathrm{v})$ $\mathrm{HNO}_{3}$ and $\mathrm{NH}_{4} \mathrm{OH}$ for $30 \mathrm{~min}$ and $60 \mathrm{~min}$, respectively. The saccharification was carried out at enzyme celullase loadings of 10 and $20 \mathrm{FPU} / \mathrm{g}$ and substrate loadings of 10 and $20 \mathrm{~g}$ for $\mathrm{NH}_{4} \mathrm{OH}$ pretreated samples. Fermentation was carried out using two methods i.e. separated hydrolysis and fermentation (SHF) and simultaneous saccharification and fermentation (SSF) techniques. The results showed that pretreatment using $\mathrm{NH}_{4} \mathrm{OH}$ was more effective than $\mathrm{HNO}_{3}$ for 60 minutes. IFurthermore, the results also presented the reduction of the lignin content of $9.44 \%$ and the increase of cellulose content to $18.56 \%$ for $1 \%(\mathrm{v} / \mathrm{v}) \mathrm{NH}_{4} \mathrm{OH} 60 \mathrm{~min}$ of pretreatment. The increase of enzyme cellulase (20 FPU/g substrate) and substrate loading $(20 \mathrm{~g})$ could produce more reducing sugar $(17.423 \mathrm{~g} / \mathrm{L}$ and $19.233 \mathrm{~g} / \mathrm{L})$ than that at 10 FPU/g substrate and $10 \mathrm{~g}$ substrate $(11.423 \mathrm{~g} / \mathrm{L}$ and $17.423 \mathrm{~g} / \mathrm{L})$, respectively. The comparison of SHF and SSF showed that SHF process yielded higher ethanol $(8.11 \mathrm{~g} / \mathrm{L})$ as compared to SSF $(3.95 \mathrm{~g} / \mathrm{L})$ and nontreatment process $(0.507 \mathrm{~g} / \mathrm{L})$ for $72 \mathrm{~h}$..
\end{abstract}

\section{Introduction}

World oil reserves continue to decrease, it is estimated that global oil production will decrease from 25 million to 5 million barrels in 2050 [1]. Bioethanol is one of the renewable energy that is used to reduce the dependence on petroleum fuels and environmental impacts [2]. Bioethanol fuel production from starch sources have been widely applied especially in USA and Brazil. The current biofuel production has been moved towards nonfood raw materials, such as forestry or agricultural residues. Sugar palm trees (Arenga pinnata) or known locally as Aren Palm is one of the potential sources which have been identified for bioethanol production [3]. To increase the use of the potential sugar palm plants, a large scale sugar palm plantations which is as wide as 800,000 to $4,000,000$ ha have been developed in Indonesia [4]. The sugar sap from its flower stalks is the most prominent of aren's products. Besides, the sugar palm tree also generates edible fruits, starch from trunk and fibres for building material and household utensils [4], [5]. Flour (starch) is obtained from the extraction of the central part of the stem after the palm tree is no longer producing sap [6]. Starch free sugar palm trunk (SFSPT) is a solid waste derived from sugar palm starch extraction. Dry SFSPT is comprised of lignin $(37 \%$ $\mathrm{w} / \mathrm{w})$, cellulose and hemicellulose (49.5\%). Lignocellulose from industrial waste palm flour, SFSPT, (Arenga pinnata) can be used to manufacture of bioethanol therefore the environmental damage can be reduced. Bioethanol is produced by fermentation of the fermentable sugars generated by enzymatic hydrolysis of cellulose and hemicellulose which are structural carbohydrates. However, lignin is a complex aromatic polymer that forms a cover surrounding the carbohydrate fractions that are limiting the accessibility of carbohydrates to hydrolytic enzymes. Therefore, delignification is important to improve enzymatic digestibility of lignocellulose [7].

Pretreatment is necessary to degrade lignin in bamboo culms to enable bioethanol production as the bamboo lignin network prevents enzymatic saccharification and fermentation [8]. Tutt et al. [9], reported the effect of pretreatment with a dilute solution

Corresponding author: kusmiyati@ums.ac.id and psea_ums2014@yahoo.com 
of sulfuric acid, hydrochloric acid, nitric acid and potassium hydroxide, followed by enzymatic hydrolysis of pretreated wheat straw and subsequent fermentation to ethanol. The highest glucose concentration of $316.7 \mathrm{~g} / \mathrm{kg}$ biomass and the lowest $(221.3 \mathrm{~g} / \mathrm{kg})$ were achieved by pretreatment with nitric acid and hydrochloric acid, respectively. The best ethanol yield of $104.3 \mathrm{~g} / \mathrm{kg}$ was achieved by samples pretreated with $\mathrm{KOH}$ (rinsed). In another study by Jeong and Lee [10] pretreatment of yellow poplar biomass with oxalic acid which showed the structural was changed for pretreated biomassa. The increasing severity of pretreatment resulted an gradual increased of biomass degradation rate which caused the increased crystallinity value and the surface area of the pretreated biomass. Effect of nitric acid on pretreatment for ethanol production of rice straw has been studied by Kim et al. [11], pretreatment conditions were $\mathrm{HNO}_{3}$ concentration $(0.2-1.0 \%)$, temperature $\left(120-160{ }^{\circ} \mathrm{C}\right)$ and reaction time (1-20) min. A maximum xylose yield of $86.5 \%$ and an enzymatic digestibility of $83.0 \%$ were achieved at a condition of $0.65 \% \mathrm{HNO}_{3}, 158.8^{\circ} \mathrm{C}$ and $5.86 \mathrm{~min}$. Pretreatment of sorghum fibers with ammonium hydroxide followed by enzyme hydrolysis of pretreated fiber and subsequent ethanol production have been evaluated. The treatments removed $44 \%$ lignin and $35 \%$ hemicellulose at a ratio of 1:0.14:8 sorghum fibers, ammonia, and water, $160^{\circ} \mathrm{C}$ for $1 \mathrm{~h}$ under $140-160 \mathrm{psi}$ pressure. Ethanol yields were $25 \mathrm{~g} / 100 \mathrm{~g}$ dry biomass and $10 \mathrm{~g}$ ethanol/100 $\mathrm{g}$ dry biomass for treated and untreated biomass, respectively [12].

The objective of this study was to evaluate the effect of pretreatments of starch free sugar palm trunk (SFSPT) using dilute nitric acid and ammonium hydroxide on the hydrolysis and subsequent fermentation using Simultaneous Saccharification and Fermentation (SSF) and Separated Hydrolysis and Fermentation (SHF) methods to produce ethanol. The comparison of fermentation by SHF and SSF were also evaluated.

\section{Materials and Methods}

\subsection{Feedstock Materials}

Lignocellulose biomass (Arenga pinnata) was taken from solid waste of the palm starch production house located in Klaten, Central Java Indonesia. Sugar palm trunk, usually brought to the plant in pieces about four feet high. Furthermore, palm trunks are milled using a milling machine to get trunks powder. To extract the palm starch from palm trunk powder by pouring the powder with water continuously and subsequent filtered to separate starch and solid waste containing cellulose. The solid waste or biomass fibre of starch-free sugar palm trunk (SFSPT) was dried in the sun to dry $(+2-3$ days) then it was milled to small particles by a grinding with machine and sieved to obtain a size 40 mesh and subsequent stored in a dry place prior to use. The starchfree sugar palm trunk (SFSPT) was composed of $23.96 \%$ cellulose, $26.82 \%$ hemicelluloses, and $18.57 \%$ lignin based on its dry weight [13].

\subsection{Pretreatment}

Starch-free sugar palm trunk (SFSPT) substrate added with alkaline solution of $1 \%(\mathrm{v} / \mathrm{v}) \mathrm{NH}_{4} \mathrm{OH}$ or acid solution $1 \%(\mathrm{v} / \mathrm{v}) \mathrm{HNO}_{3}$ at concentration of $50 \mathrm{~g} / 500 \mathrm{ml}$ solution was pretreated in an autoclave for $30 \mathrm{~min}$ or 60 min at temperature $120^{\circ} \mathrm{C}$. The samples were filtered with whatman filter paper to separate solids and liquids, the the pretreated solids was washed repeatedly with distilled water until pH 7 (neutral). The pretreated solid (SFSPT) was dried using an oven at a temperature of $65^{\circ} \mathrm{C}$ to obtain a constant weight. The pretreated solids (SFSPT) are stored for further use as raw material for hydrolysis.

\subsection{Enzymatic Hydrolysis}

Non treatment and The pretreated solid SFSPT $\left(\mathrm{NH}_{4} \mathrm{OH}\right.$ $1 \%(\mathrm{v} / \mathrm{v})$ for $60 \mathrm{~min})$ was hydrolyzed using commercial cellulase enzyme (SQzyme CSP, China). Hydrolysis was conducted in a $500 \mathrm{~mL}$ erlenmeyer flask containing 200 $\mathrm{mL}$ of $50 \mathrm{mM}$ sodium acetate buffer solution and loaded with $20 \mathrm{~g}$ substrate, $0.5 \mathrm{~g}$ yeast extract, $1 \mathrm{~g}$ peptone. The $\mathrm{pH}$ was adjusted to 4.8 using hydrochloric acid. The flasks were autoclaved at $121^{\circ} \mathrm{C}$ for $20 \mathrm{~min}$. After the flasks was cooled to $30^{\circ} \mathrm{C}$, the cellulase enzyme was loading at $10 \mathrm{FPU} / \mathrm{g}$ substrate or $20 \mathrm{FPU} / \mathrm{g}$ substrate. The hydrolysis was conducted in a shaker incubator for $72 \mathrm{~h}$ at $150 \mathrm{rpm}$ and temperature $50^{\circ} \mathrm{C}$. Samples were taken for analysis of reducing sugars.

\subsection{Inoculum Preparation}

\subsubsection{Preculture of Aspergillus Niger}

Isolates of Aspergillus niger was subculture in test tubes slant containing PDA (Potato Dextrose Agar) and incubated at $30^{\circ} \mathrm{C}$ for $72 \mathrm{~h}$. To enrich amount of cell, so must be preculture. Making pre-cultur in $100 \mathrm{~mL}$ consists of $1 \mathrm{~g}\left(\mathrm{NH}_{4}\right)_{2} \mathrm{SO}_{4} ; 0.3 \mathrm{~g}$ urea; $0.3 \mathrm{~g} \mathrm{KH}_{2} \mathrm{PO}_{4}$; $0.05 \mathrm{~g} \mathrm{MgSO}_{4} .7 \mathrm{H}_{2} \mathrm{O} ; 0.05 \mathrm{~g} \mathrm{CaCl}_{2}$, Autoclave $121^{\circ} \mathrm{C}$ for $20 \mathrm{~min}$, shaker $120 \mathrm{rpm}$, incubation time $72 \mathrm{~h}$.

\section{4.2 Preculture of Saccharomyces cerevisiae}

Isolates of Saccharomyces cerevisiae was subculture in $100 \mathrm{~mL}$ and divided into 10 reaction tubes slant containing $2 \mathrm{~g}$ glucose; $2 \mathrm{~g}$ peptone; $1 \mathrm{~g}$ yeast extract, and $1.5 \mathrm{~g}$ agar. To increase the amount of cells that must be preculture, preculture made in $100 \mathrm{~mL}$ containing 0.2 $\mathrm{g}\left(\mathrm{NH}_{4}\right)_{2} \mathrm{HPO}_{4} ; 0.64 \mathrm{~g}$ urea; 0.2 g $\mathrm{KH}_{2} \mathrm{PO}_{4} ; 0.1 \mathrm{~g}$ $\mathrm{MgSO}_{4} \cdot 7 \mathrm{H}_{2} \mathrm{O}$. Sterilization $121^{\circ} \mathrm{C}$ for $20 \mathrm{~min}$, shaker $120 \mathrm{rpm}$, incubation time $72 \mathrm{~h}$.

\subsubsection{Main culture of Aspergillus niger}

In order to be used Aspergillus niger should familiarized with the addition of the substrate. Making 2 main culture in $200 \mathrm{~mL}$ and $20 \mathrm{~mL}$ plus preculture consists of $4 \mathrm{~g}$ substrate which has been in treatment; $2 \mathrm{~g}$ yeast; 4 g peptone; $2 \mathrm{~g}\left(\mathrm{NH}_{4}\right)_{2} \mathrm{HPO}_{4} ; 0.6 \mathrm{~g}$ urea; $0.6 \mathrm{~g}$ 
$\mathrm{KH}_{2} \mathrm{PO}_{4} ; 0.1 \mathrm{~g} \mathrm{MgSO}_{4} .7 \mathrm{H}_{2} \mathrm{O}$. Autoclave $121^{\circ} \mathrm{C}$ for 20 min, main culture incubated for $72 \mathrm{~h}$ and $120 \mathrm{rpm}$ shaker.

\subsubsection{Main culture of Saccharomyces cerevisiae}

Saccharomyces cerevisiae start to familiarized with the addition of the substrate, making main culture in $200 \mathrm{~mL}$ (+ $20 \mathrm{~mL}$ preculture) consisting of $4 \mathrm{~g}$ substrate which has been in treatment; $2 \mathrm{~g}$ yeast; $4 \mathrm{~g}$ peptone; $0.4 \mathrm{~g}$ $\left(\mathrm{NH}_{4}\right)_{2} \mathrm{HPO}_{4} ; 1.2$ g urea; $0.4 \quad \mathrm{~g} \quad \mathrm{KH}_{2} \mathrm{PO}_{4} ; 0.2 \mathrm{~g}$ $\mathrm{MgSO}_{4} \cdot 7 \mathrm{H}_{2} \mathrm{O}$. Autoclave $121^{\circ} \mathrm{C}$ for $20 \mathrm{~min}$, main culture was incubation for $72 \mathrm{~h}$ and $120 \mathrm{rpm}$ shaker.

\subsection{Simultaneous Saccharification and Fermentation (SSF) And Separated Saccharification and Fermentation (SHF)}

Solid substrate without pretreatment and previously pretreated with $1 \%(\mathrm{v} / \mathrm{v}) \mathrm{NH}_{4} \mathrm{OH}$ autoclave for 60 min at $121^{\circ} \mathrm{C}$ and hydrolized with $20 \mathrm{FPU}$ and $20 \mathrm{~g}$ subtrate for $72 \mathrm{~h}$ was fermented with Saccharomyces cerevisiae alone for SHF method. For SSF Saccharomyces cerevisiae and Aspergillus niger was used. Biomass $50 \mathrm{~g}$ in $500 \mathrm{~mL}$ solution, mainculture Saccharomyces cerevisiae added $1 \mathrm{~mL} / \mathrm{g}$ and mainculture Aspergillus niger $1 \mathrm{~mL} / \mathrm{g}$. Fermentation for $72 \mathrm{~h} 30^{\circ} \mathrm{C}$. Shaker for $72 \mathrm{~h}$, after $72 \mathrm{~h}$ is done, then distillation to separate the liquid and the substrate. Ethanol was obtained stored at a temperature of $20^{\circ} \mathrm{C}$.

\section{Result and Discussion}

\subsection{Effect of Acids and Alkaline pretreatments on Lignin, Hemicellulose and Cellulose}

Amount of Lignocellulosic biomass is very abundant and can be converted to energy using technology [14]. Lignocellulosic biomass contains lignin which envelops cellulose, lignin will inhibit the enzyme accessibility and can decrease the rate of hydrolysis [8]. Biomass palm trunks can not be directly fermented due to very rich content of lignin, so that necessary to delignification treatment with the addition of acids and alkaline. Delignification also affected by pretreatment time and temperature. Long treatment time will effect to high cellulose [15]. Breakdown of lignin very necessary to remove the cellulose contained.

In Fig 1, can be seen initial lignin content of the raw material, after treatment with $\mathrm{HNO}_{3}$ and $\mathrm{NH}_{4} \mathrm{OH}$, the lignin content in raw materials has decreased, both with pretreatment using $\mathrm{HNO}_{3}$ and $\mathrm{NH}_{4} \mathrm{OH}$. The maximum decrease of lignin obtained for pretreatment $1 \%(\mathrm{v} / \mathrm{v})$ $\mathrm{HNO}_{3}$ is $8.28 \%$ for 60 min treatment and $1 \%$ (v/v) $\mathrm{NH}_{4} \mathrm{OH}$ is $9.44 \%$ for $60 \mathrm{~min}$ treatment. while the hemicellulose content varies in each treatment, and the content of cellulase has increased significantly. The maximum increase in the cellulose treatment $1 \%(\mathrm{v} / \mathrm{v})$ $\mathrm{HNO}_{3}$ is $17.33 \%$ and $1 \%(\mathrm{v} / \mathrm{v}) \mathrm{NH}_{4} \mathrm{OH}$ treatment to a maximum is $18.56 \%$ for $60 \mathrm{~min}$ treatment. This indicates the acidic and alkaline pretreatment can damage lignin [16], so the content of cellulose can be out and will be converted into sugar and then fermented using Saccharomyces cerevisiae to produce ethanol.
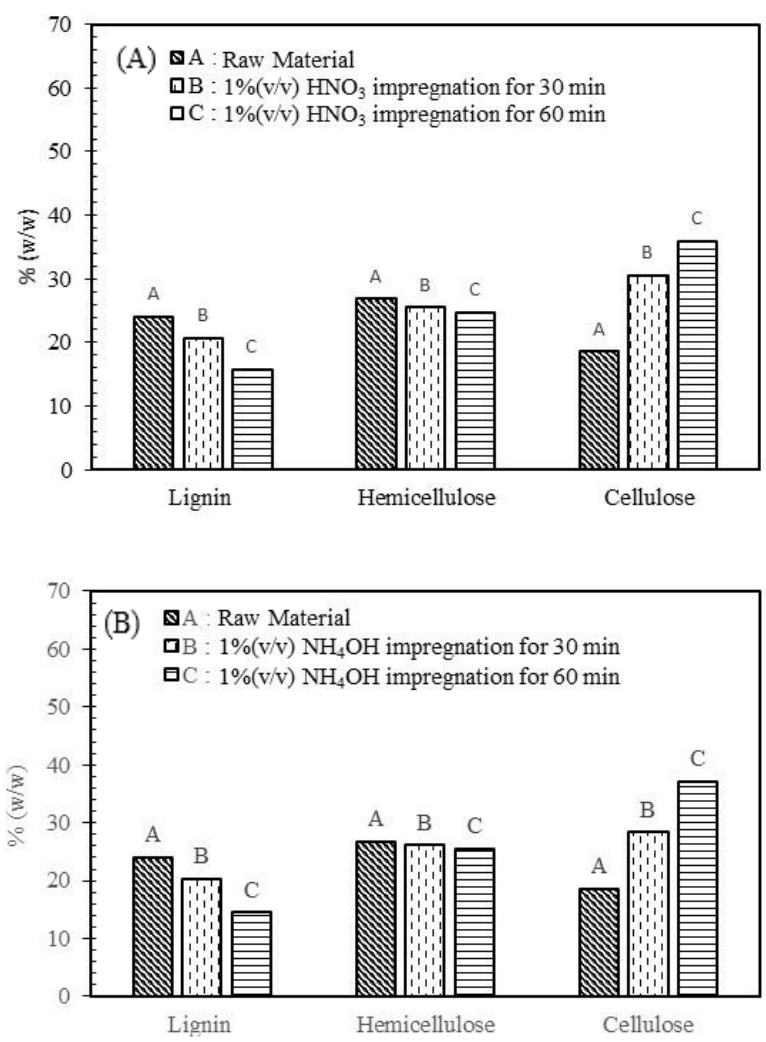

Fig. 1. Lignin after pretreatment using (A) $1 \%(\mathrm{v} / \mathrm{v}) \mathrm{HNO}_{3}$ for Non-impregnation; Impregnation of $30 \mathrm{~min}$ and $60 \mathrm{~min}$. (B) $1 \%(\mathrm{v} / \mathrm{v}) \mathrm{NH}_{4} \mathrm{OH}$ to Non-impregnation; Impregnation $30 \mathrm{~min}$ and $60 \mathrm{~min}$.

\subsection{Relations with reduced sugar content of ethanol after fermentation}

When fermented, amount of reduced sugar content greatly affect amount ethanol produced. Levels of bioethanol produced with SFF treatment process using $1 \%(\mathrm{v} / \mathrm{v}) \mathrm{NH}_{4} \mathrm{OH}$ produce high levels greater than the levels of ethanol using $1 \%(\mathrm{v} / \mathrm{v}) \mathrm{HNO}_{3}$ pretreatment SSF. Characteristic of pretreatment alkaline are able to eliminate lignin without having a great effect to other components [17]. The highest ethanol is $3.91 \mathrm{~g} / \mathrm{L}$ for 60 $\min 1 \%(\mathrm{v} / \mathrm{v}) \mathrm{NH}_{4} \mathrm{OH}$ treatment and $2.73 \mathrm{~g} / \mathrm{L}$ for $1 \%$ (v/v) $\mathrm{HNO}_{3}$ treatment. Pretreatment of acids and alkaline aim to improve the yield of sugar, for the next can be converted into ethanol using $S$. cereviciae. Pretreatment with alkaline, when compared with the acid or enzymes may increase 8 times and 23 times the yield of fermentable sugars [18]. From the literature, pretreatment on wheat straw with dilute $\mathrm{HNO}_{3}$ gave an ethanol yield of only $95.0 \mathrm{~g} . \mathrm{kg}^{-1}$ and highest glucose yield (316.7 g. $\left.\mathrm{kg}^{-1}\right)$ [9]. Saha et al. (2013) reported that $\mathrm{NH}_{4} \mathrm{OH}$ is the best pretreatment on pteris and could produce $0.642 \mathrm{mg} / \mathrm{ml}$ reducing sugar and $0.333 \mathrm{mg} / \mathrm{L}$ ethanol with $0.075 \mathrm{gm}$ of yeast at $50 \mathrm{~h}$ under the conditions $\mathrm{pH} 7,35^{\circ} \mathrm{C}$, substrate diameter $45 \mu \mathrm{m}-63 \mu \mathrm{m}$, 
substrate loading $0.25 \mathrm{gm}$ in $100 \mathrm{ml}$ working volume [19].

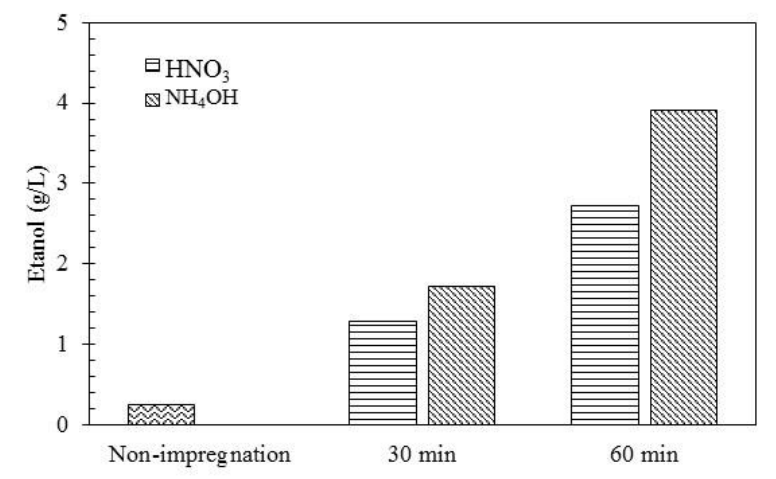

Fig. 2. Bioethanol after fermentation (SSF $72 \mathrm{~h}$ ) $1 \%(\mathrm{v} / \mathrm{v})$ $\mathrm{HNO}_{3}, 1 \%(\mathrm{v} / \mathrm{v}) \mathrm{NH}_{4} \mathrm{OH}$ and non-impregnation; impregnation for $30 \mathrm{~min}$ and $60 \mathrm{~min}$ with $20 \mathrm{FPU} / \mathrm{g}$ substrate enzyme loading and $20 \mathrm{~g}$ substrate.

\subsection{Correlation between reducing sugar and ethanol in SHF and SSF processes}

Enzyme loading for the hydrolysis of biomass palm trunks used 10 and $20 \mathrm{FPU} / \mathrm{g}$ celluclast. Raw materials used previously have been treated by $\mathrm{NH}_{4} \mathrm{OH} 60$ menit. As seen in fig 3, the maximum yield achieve of glucose produced by the enzyme loading $20 \mathrm{FPU} / \mathrm{g}$ celluclast and $20 \mathrm{~g}$ substrate is $19.223 \mathrm{~g} / \mathrm{L}$, while the glucose produced with non treatment is $1.718 \mathrm{~g} / \mathrm{L}$. Increasing the amount of celluclast and hydrolysis time will be proportional to the increase in the amount of glucose produced. Ayeni et al. [20], reported the highest reducing sugar on shea tree sawdust in 4 day hydrolysis time, $50 \mathrm{FPU} / \mathrm{g}$ dry biomass, $45^{\circ} \mathrm{C}, \mathrm{pH} 4.8,40 \mathrm{~g} / \mathrm{L}$ substrate concentration was 482.40 $\mathrm{mg} / \mathrm{g}$ dry biomass. In variations of the use of enzymes cellucase SHF process will affect the content of reducing sugar produced, can be seen in graph A, where the variation of cellulase enzymes $20 \mathrm{FPU} / \mathrm{g}$ produces $(17.423 \mathrm{~g} / \mathrm{L}$ for $72 \mathrm{~h})$, more reduced sugar content than $10 \mathrm{FPU} / \mathrm{g}$ variation $(11.423 \mathrm{~g} / \mathrm{L}$ for $72 \mathrm{~h})$, while the non treatment produced $1.718 \mathrm{~g} / \mathrm{L}$ for $72 \mathrm{~h}$. To effect substrate amount of raw materials also affect the content of reducing sugar obtained when the hydrolysis process is carried out on raw materials. In the graph (B), shown by the increasing amount of substrate then reducing sugar obtained is also greater. The variation of $20 \mathrm{~g}$ substrate could produced $19.233 \mathrm{~g} / \mathrm{L}$ than $10 \mathrm{~g}$ substrate was $17.423 \mathrm{~g} / \mathrm{L}$ and non treatment was obtained 1.718 $\mathrm{g} / \mathrm{L}$ for $72 \mathrm{~h}$. In this stage of saccharification enzyme, modified cellulose into cellobiose and further into simple sugars such as glucose, saccharification process using enzymes celluclast, enzyme hydrolysis process takes place at $\mathrm{pH} 4.8$ and the temperature of $45-50^{\circ} \mathrm{C}$ [21]. From Ganguly et al. [22], and Aveni et al. [20], the addition of biomass loading and hydrolysis time influences increase in reducing sugar, the maximum substrate loading to produces highest reducing sugar is $7 \%$ for $27.78 \mathrm{mg} / \mathrm{g}$ while the $40 \mathrm{~g} / \mathrm{L}$ substrate concentration could produce maximum sugar yield for $42.4 \%$.
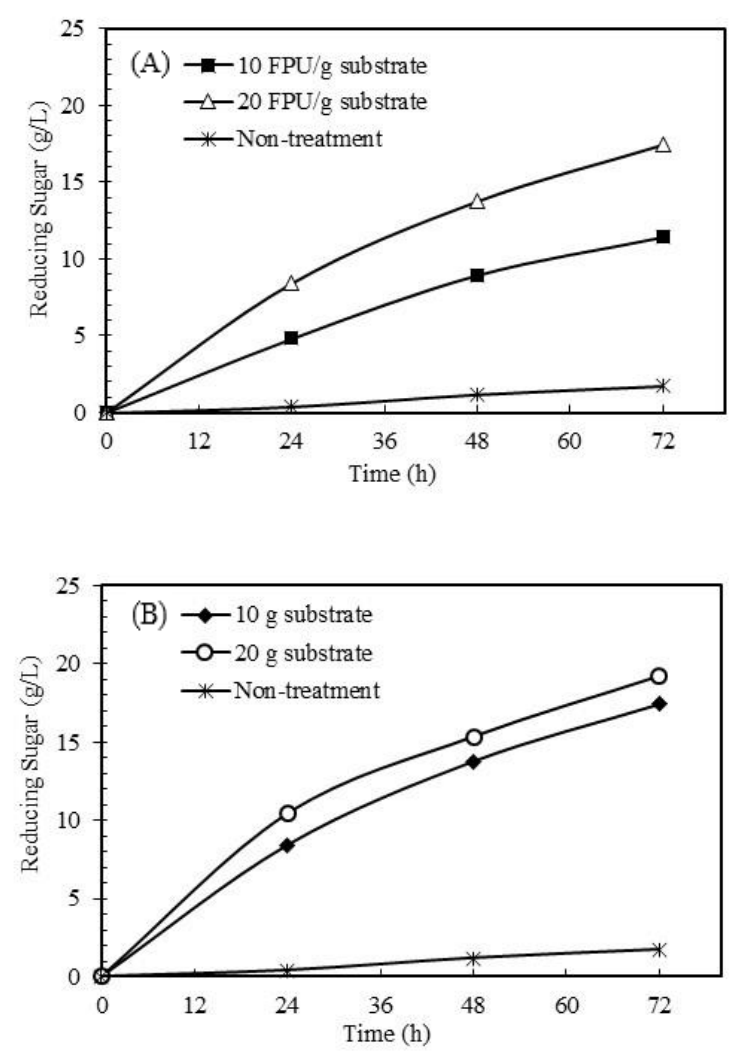

Fig. 3. (A) Graph reduction sugar versus time with $10 \mathrm{~g}$ substrate $\left(1 \%(\mathrm{v} / \mathrm{v}) \mathrm{NH}_{4} \mathrm{OH}\right.$ treatment for $\left.60 \mathrm{~min}\right)$, the enzyme loading $10 \mathrm{FPU} / \mathrm{g}$ substrate and $20 \mathrm{FPU} / \mathrm{g}$ substrate, while (B) The relationship of reducing sugar versus time with substrate loading $10 \mathrm{~g}$ and $20 \mathrm{~g}\left(1 \%(\mathrm{v} / \mathrm{v}) \mathrm{NH}_{4} \mathrm{OH}\right.$ treatment for $60 \mathrm{~min}$, $20 \mathrm{FPU} / \mathrm{g}$ substrate enzyme loading).

In the use of this type of fermentation process between SHF and SSF, have some differences apart in terms of stages and the time required in the process. SHF process to produce bioethanol is higher, and less energy is required and the production cost can be minimized. SHF process for treatment and nontreatment used 20 FPU/g substrate enzyme loading and $20 \mathrm{~g}$ substrate $(1 \%$ (v/v) $\mathrm{NH}_{4} \mathrm{OH}$ impregnation for $60 \mathrm{~min}$ ).

As It is presented by fig 5, the concentration of bioethanol using the process of SHF was higher as compared to one obtained by using the SSF. Fig 5 also shows that from the graph (A) and (B) it appears that the fermentation time for $72 \mathrm{~h}$, concentrations of bioethanol on the two types of fermentation process has a very significant difference in the SHF obtained biethanol concentration of $8.11 \mathrm{~g} / \mathrm{L}$, while the non treatment was obtained $0.57 \mathrm{~g} / \mathrm{L}$. The SSF process derived bioethanol concentration of $3.95 \mathrm{~g} / \mathrm{L}$, while the non treatment was obtained $0.57 \mathrm{~g} / \mathrm{L}$. 

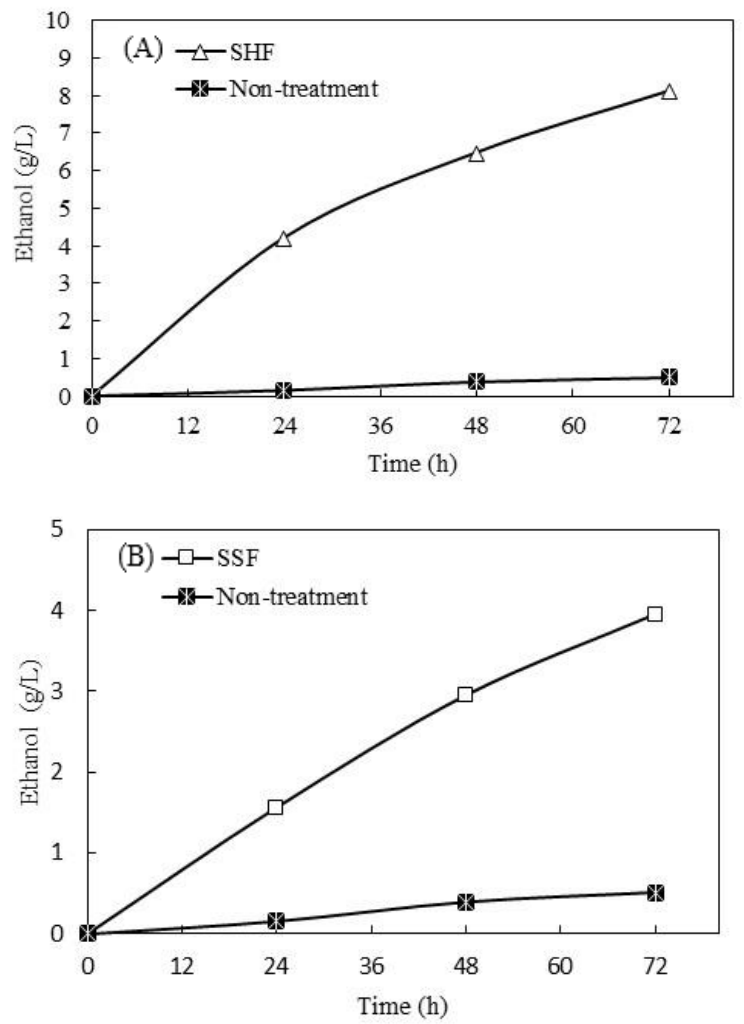

Fig. 4. (A) graph ethanol on fermentation time for the SHF with $1 \%(\mathrm{v} / \mathrm{v}) \mathrm{NH}_{4} \mathrm{OH}$ for $60 \mathrm{~min}, 20 \mathrm{FPU} / \mathrm{g}$ substrate cellulase and $20 \mathrm{~g}$ substrate biomass loading, (B) graph ethanol on the SSF fermentation process with $1 \%(\mathrm{v} / \mathrm{v}) \mathrm{NH}_{4} \mathrm{OH}$ for $60 \mathrm{~min}$, $20 \mathrm{FPU} / \mathrm{g}$ substrate cellulase and $20 \mathrm{~g}$ substrate biomass loading.

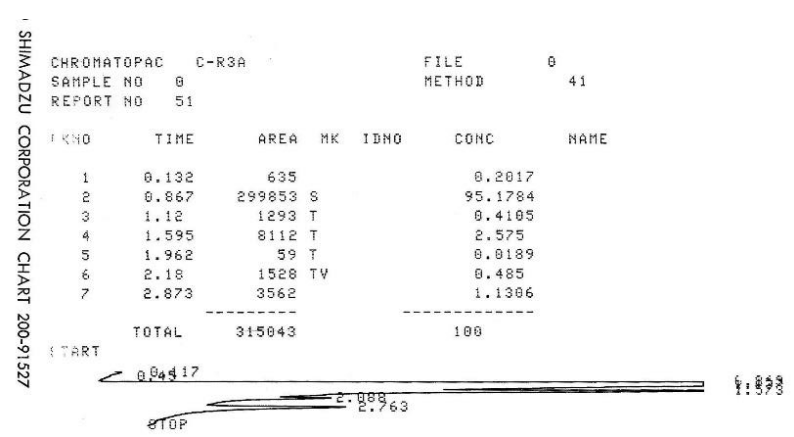

Fig. 5. Graph ethanol GC

GC graph showing measurements of bioethanol for the SHF and SSF.

\section{Conclusion}

Lignocellulose from industrial waste palm flour, SFSPT, can produce an ethanol with several processes, pretreatment, saccharification and fermentation. Pretreatment SFSPT with $\mathrm{NH}_{4} \mathrm{OH}$ was more effective than $\mathrm{H}_{3} \mathrm{PO}_{4}$ for $60 \mathrm{~min}$ impregnation. The more celluclast and substrate loading has a greater reducing sugar $(17.3 \mathrm{~g} / \mathrm{L}$ for $20 \mathrm{FPU} / \mathrm{g}$ and $19.2 \mathrm{~g} / \mathrm{L}$ for $20 \mathrm{~g}$ substrate) for 72 hours saccharification. SHF process significantly produce higher ethanol than SSF process for 72 hours $(8.11 \mathrm{~g} / \mathrm{L}$ for SHF and $3.95 \mathrm{~g} / \mathrm{L}$ for SSF) for $72 \mathrm{~h}$ fermentation.

\section{Acknowledgements}

The authors would like to thank the Directorate of Research and Community Service, Ministry of Education, Technology and Higher Education Indonesia (Kemenristekdikti) for funding this Research (PB Kompetensi 2017).

\section{References}

1. Y. Sun and J. Cheng, Bioresour. Technol., 83, 1-11 (2002)

2. M. Galbe and G. Zacchi, Microbiol Biotechnol, 59, 618-628, 2002

3. H. Lantemona, A. L. Abadi, A. Rachmansyah, and J. Pontoh, IOSR J. Environ. Sci. Toxicol. Food Technol., 4, 2, 42-48 (2013)

4. E. Martini, J. M. Roshetko, M. Van Noordwijk, A. Rahmanulloh, E. Mulyoutami, and S. Budidarsono, Agrofor. Syst., 86, 3, 401-417 (2008)

5. M. R. Ishak, S. M. Sapuan, Z. Leman, M. Z. A. Rahman, U. M. K. Anwar, and J. P. Siregar, Carbohydr. Polym., 91, 2, 699-710 (2013)

6. M. Lempang, Info Tek. EBONI, 9, 1, 37-54 (2012)

7. J. Xu, Y. Chen, J. J. Cheng, R. R. Sharma-Shivappa, and J. C. Burns, BioResources, 6, 707-720 (2011)

8. H. Suhara, S. Kodama, I. Kamei, N. Maekawa, and S. Meguro, Int. Biodeterior. Biodegradation, $\mathbf{7 5}$, 176-180 (2012)

9. M. Tutt, T. Kikas, and J. Olt, Agron. Res. Biosyst. Eng. Spec. Issue, 1, 269-276 (2012)

10. S.-Y. Jeong and J.-W. Lee, Ind. Crop. Prod., 79, 1-6 (2016)

11. I. Kim, B. Lee, J.-Y. Park, S.-A. Choi, and J.-I. Han, Carbohydr. Polym., 99, 563-567 (2014)

12. D. A. Salvi, G. M. Aita, D. Robert, and V. Bazan, $J$. Ind. Microbiol. Biotechnol, 37, 27-34 (2010)

13. J. Sahari, S. M. Sapuan, Z. N. Ismarrubie, and M. Z. A. Rahman, Fibres Text. East. Eur., 2, 91, 21-24 (2012)

14. B. Butkutè, N. Lemežienè, and J. Cesevičienè, Zamdirbyste-Agriculture, 100, 3, 251-260 (2013)

15. X.-D. Hou, T. J. Smith, N. Li, and M.-H. Zong, Biotechnol. Bioeng., vol. xxx, no. xxx, 1-10 (2012)

16. E. C. Bensah and M. Mensah, Int. J. Chem. Eng., 2013, 1-21 (2013)

17. J. D. McMillan, Renew. Energy, 10, 2/3, 295-302 (1997)

18. L. C. G. Filho, G. A. A. Fischer, N. Sellin, C. Marangoni, and O. Souza, J. Environ. Sci. Eng., 2, 65-69 (2013)

19. P. Saha, A. C. Baishnab, F. Alam, M. R. Khan, and A. Islam, Procedia Eng., 90, 504-509 (2014)

20. A. O. Ayeni, J. A. Omoleye, F. K. Hymore, and R. A. Pandey, Brazilian J. Chem. Eng., 33, 1, 33-45, (2016) 
21. E. Hermiati, D. Mangunwidjaja, T. C. Sunarti, and O. Suparno, J. Litbang Pertan., 29, 4, 121-130 (2010)

22. A. Ganguly, S. Das, A. Bhattacharya, A. Dey, and P. K. Chatterjee, Indian J. Exp. Biol., 51, 556-566 (2013) 